J. Clin. Chem. Clin. Biochem.

Vol. 20, 1982, pp. 491-498

\title{
The Determination of Calcium, Glucose, Urea and Uric Acid Using the Kodak EKTACHEM Multilayer Film Technology: An Evaluation
}

By E. Knoll

Department of Clinical Chemistry, Robert-Bosch-Krankenhaus, Stuttgart

F. Hafner

Clinical Chemistry Products, Kodak AG, Stuttgart

K. Dettmer and H. Wisser

Department of Clinical Chemistry, Robert-Bosch-Krankenhaus, Stuttgart

(Received November 12, 1981/Februar 2, 1982)

Summary: Calcium, glucose, urea and uric acid determinations on the "Kodak Ektachem Four Chemistry Analyzer" were tested for precision and an estimation of the accuracy was performed with our laboratory routine methods using patients' sera and proficiency fluids. Precision - examined over a period of six weeks - was very good. Even the very stringent claim of the College of American Pathologists (CAP) - that analytical dispersion should be less than $1 / 16$ th of the normal range - was fulfilled in almost all control samples. The results from patients' sera measured using both the Ektachem and the routine laboratory methods showed very good correlation. Proficiency fluids tested for calcium, glucose and uric acid all resulted in values well within the assigned interval. Some negative bias was noted for the urea determination however. This could not be completely eliminated even though the samples had been reconstituted with a bicarbonate solution according to the manufacturer's instructions. The linear range of the four determinations was checked: calcium is linear up to $4.2 \mathrm{mmol} / 1$, glucose up to $33 \mathrm{mmol} / \mathrm{l}$, urea up to $60 \mathrm{mmol} / 1$ and uric acid up to $1370 \mu \mathrm{mol} / 1$.

Our results confirmed the longtterm stability of the analyzer and slides to be so high that one calibration per week is sufficient.

Die Bestimmung von Calcium, Glucose, Ḧarnstoff und Harnsäure mit der Kodak EKTACHEM Mehrschichtenfilm-Technologie: Eine Evaluierung

Zusammenfassung: Die Präzision der Calciumm-, Glucose-, Harnstoff: und Harnsäurebestimmung mit dem „Kodak Ektachem Four Chemistry Analyzer" wurde untersucht und die Richtigkeit wurde durch Methodenvergleiche mit den Routineverfahren unseres Laboratotiums mit Patientenseren und Kontrollproben geprüft. Die Präzision - unter-sucht über einen Zeitraum von sechs Wochen - war sehr gut. Sogar die sehr weitgehende Forderung des „College of American Pathologists" (CAP) - daßß die analytische Streuung kleiner als 1/16 des Normalbereichs sein sollte - war in nahezu allen Kontrollproben erfullt.

Die Ergebnisse von Patientenseren mit den Ektachem- und Routineverfahren zeigten eine sehr gute Ubereinstimmung. Bei den Kontrollproben waren die Ergebnisse für Calcium, Glucose und Harnsäure immer im Sollwertbereich. Die Harnstoffbestimmung ergab jedoch mit dem Ektachem-Verfahren eine negative Abweichung. Dieser Effekt konnte auch durch das von der Herstellerfirma empfohlene Auflösen der Proben in Hydrogencarbonatlösung nicht ganz beseitigt werden. Es wurden folgende linearen Meßbereiche mit den vier Ektachem-Verfahren ermittelt: Calcium bis $4,2 \mathrm{mmol} / 1$, Glucose bis $33 \mathrm{mmol} / 1$, Harnstoff bis $60 \mathrm{mmol} / 1$ und Harnsäure bis $1370 \mu \mathrm{mol} / 1$.

Unsere Ergebnisse zeigen, daß die Langzeitstabilität des Gerätes und der Analysenplättchen so gut ist, daß eine Kalibration pro Woche ausreicht. 


\section{Introduction}

Dry reagent carriers for qualitative clinical chemistry analyses in urine have been in use for some time. It was recently reported that a new analysis method had been developed enabling the quantitative determination of substrates and enzymes in serum and plasma (1-3). This method utilizes dry multilayer thin-film analytical elements (slides) for use in the Kodak Ektachem Four Chemistry Analyzer (Eastman Kodak Company). We tested an engineering model of this analyzer in our laboratory over a period of about three months in order to examine precision, accuracy and practicability under normal working conditions. During this time the quantitative serum determinations which can be performed by this analyzer (glucose, calcium, urea and uric acid) were compared with the conventional "wet chemistry" methods normally used in our laboratory.

\section{Materials and Methods \\ Principles of the Kodak Ektachem technology}

All the reagents necessary to perform a single test are contained in dry form in a slide (fig. 1) composed of several thin layers coated on top of one another. The uppermost (spreading) layer

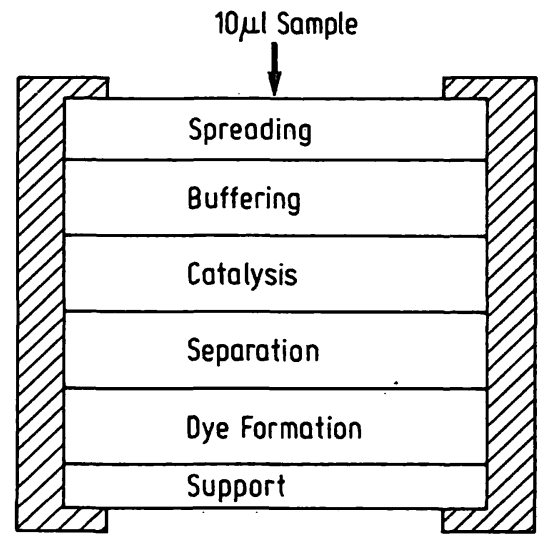

Fig. 1. Conceptual format of multilayer slides.

is a white isotropically porous layer consisting in most cases essentially of cellulose acetate and $\mathrm{TiO}_{2}$. One function of the spreading layer is to enable uniform metering and spreading of the $10 \mu$ undiluted sample, thereby ensuring even distribution and penetration of solute molecules into the layers beneath. All the reagents such as chromogens, enzymes, buffers, indicators, which are necessary for a single determination are contained in these underlying layers. The bottom layer is a transparent polyester support. The reaction which takes place within the slide during a 5-minute incubation period at $37^{\circ} \mathrm{C}$ causes dye formation. The density of the coloured compound formed is measured with a reflection spectrophotometer through the transparent support, whereby the spreading layer acts as a diffuse reflector. Calibration is carried out using 3 calibrators - lyophilized materials based on a serum matrix - which are supplied by the analyzer manufacturer.

Description of the Kodak Ektachem methods Calcium

This analytical element consists of four basic layers held on a polyester film support with various binders: spreading layer, dye- mordant layer, buffer layer and base layer. The bound calcium is dissociated from binding proteins and forms a complex with the indicator dye Arsenazo III in the dye-mordant layer (larger binding constant). The migration of the water soluble dye into the spreading layer is prevented by the use of a cationic polymer (mordant). Since calcium preferentially complexes with Arsenazo III at low $\mathrm{pH}$ values the buffer layer contains a buffer of pH 5.6. The use of 8-hydroxyquinoline to eliminate magnesium interference is therefore not required. The forming of the complex between calcium and Arsenazo III causes a shift in the absorption maximum (4). The reflection density is measured at $680 \mathrm{~nm}$.

\section{Glucose}

In this slide a spreading and a reagent layer are coated onto a polyester support. The actual method of analysis is an adaptation of the glucose oxidase-peroxidase-chromogen coupled system, first reported by Trinder (5). After oxidation of glucoose catalyzed by glucose oxidase (EC 1.1.3.4) whereby hydrogen peroxide is formed, peroxidase (EC 1.11.1.7) catalyzìes the oxidative coupling of 4-aminoantipyrine and 1,7-dihydroxynaphthalene to form a red dye. Phenol used in the original technique was replaced by the naphthalene compound, because its much lower vapour pressure makes it more suitable for the dry slide format. The formed dye is relatively insoluble in water and therefore diffusion back into the spreading layer is minimized. After incubation for 5 minutes at $37^{\circ} \mathrm{C}$ the reflection density is measured at $540 \mathrm{~nm}$.

\section{Urea}

The configuration of the urea slide is such that a spreading layer, a reagent layer, a semipermeable membrane and an indicator layer are held on a polyester support in that order. In the reagent layer the urease (EC 3.5.1.5) catalysed hydrolysis of urea to carbon dioxide and ammonia occurs. The semipermeable layer (cellulose acetate butyrate) underneath allows the ammonia to diffuse but prevents buffer or hydroxyl ions passing through. The colour forming reaction between ammonia and a protonated merocyanine dye in the indicator layer is therefore specific for ammonia (2). The dye has a broad absorption band with a maximum at $520 \mathrm{~nm}$. To increase the linear range of the assay the reflection density is measured at $670 \mathrm{~nm}$.

\section{Uric acid}

This analy tical element consists of a spreading layer, a scavenger layer and a reagent layer coated onto a polyester support. The method of analysis is based on the specific conversion of uric acid to allantoin and hydrogen peroxide in the presence of oxygen and uricase (EC 1.7.3.3). In the subsequent peroxidase catalyzed reaction, hydrogen peroxide oxidizes a leuco dye to its correspondent chromophore, the density of which is measured spectrophotometrically at $670 \mathrm{~nm}$. The scavenger layer between the spreading and reagent layer contains ascorbate oxidase (EC 1.10.3.3) which catalyzes the conversion of endogenous ascorbic acid to products which will not interfere with the subsequent reactions in the reagent layer.

\section{Description of the comparative methods Calcium}

Atomic absorption spectrophotometry (Ca/Mg-Analyzer, Beckman).

\section{Glucose}

Glucose dehydrogenase method (Gemsaec-Fast-Analyzer, Electro Nucleonics).

\section{Urea}

Urease/glutamate dehydrogenase method (Gemsaec-Fast-Analyzer).

\section{Uric acid} Uricase/aldehyde dehydrogenase method (Gemsaec-Fast-Analy-
zer). 
Protocols for precision, accuracy and linearity experiments

The precision of the four Ektachem methods was examined by measuring six (urea four) commercially available lyophilized control samples throughout a period of six weeks. The control samples were selected so as to cover a large range of concentrations for each parameter, starting well below and ending far above the respective normal ranges. Determinations were carried out in duplicate twice daily (a.m. and p.m.). Calibration was carried out once per day in the first two weeks and once per week during the remaining four weeks in order to examine the possible effects of calibration frequency on the results.

Accuracy was checked by measuring patients' sera, proficiency fluids and a set of 12 quality control samples using both the Ektachem and the comparative methods.

The linearity of the glucose, calcium and urea determinations was checked by spiking a serum pool with varying amounts of highly concentrated aqueous solutions containing the respective analyte. The linearity of the uric acid determination was checked by mixing serum with a high uric acid content $(1370 \mu \mathrm{mol} / 1)$ and serum with a low uric acid content $(120 \mu \mathrm{mol} / \mathrm{l})$ in different proportions.

\section{Results and Discussion}

\section{Precision}

The aim of the study was to establish whether statistically significant differences existed

1) between determinations carried out in the mornings and in the afternoons during a six-week period using the t-test for paired data, and

2) between determinations with daily and weekly calibration using the t-test for independent random samples $(p=0.05)$.

None of the calcium and uric acid control samples tested showed any statistically significant differences between either morning and afternoon values, or values obtained with daily and weekly calibration. Only one control sample for the glucose determination (Geo-A) showed a statistically significant difference between morning and afternoon values. The difference between morning $(\bar{x}=27.04 \mathrm{mmol} / \mathrm{l})$ and afternoon mean values $(\bar{x}=$ $27.20 \mathrm{mmol} / \mathrm{l})$ is so low however $(0.16 \mathrm{mmol} / \mathrm{l})$, that it can be disregarded. Urea samples showed no significant differences between morning and afternoon values. Three control samples however (Pathonorm L, Wellcomtrol II and Geo-A) resulted in statistically significant differences in the means obtained during the periods of daily and weekly calibration. For two control samples (Geo-A and Wellcomtrol II) mean values were higher during the weekly calibration period than during the daily calibration period: Geo-A was $0.56 \mathrm{mmol} / \mathrm{l}$ $(\Leftarrow 1.95 \%)$ higher and Wellcomtrol II was $0.7 \mathrm{mmol} / 1$ $(\hat{=} 2.2 \%)$ higher. One control sample (Pathonorm $\mathrm{L}$ ) was $0.26 \mathrm{mmol} / 1(\hat{=} 8.8 \%)$ lower with weekly calibration than with daily calibration. In practice these very small differences can be ignored.

As there are no, or only very slight, deviations in values obtained using the different calibration frequencies, it can be confirmed that daily calibration is not essential.
Using calcium as an example the results obtained for three control sera, studied throughout the period of weekly calibration, are shown in figure 2 as a cumulative summation chart (cusum-chart). The three curves can be divided into four sections, whereby the constant increase/decrease within one week emphasizes the high stability of the calibration. The time period between two calibrations should not exceed one week however, in order to avoid establishing a systematic deviation in one direction.

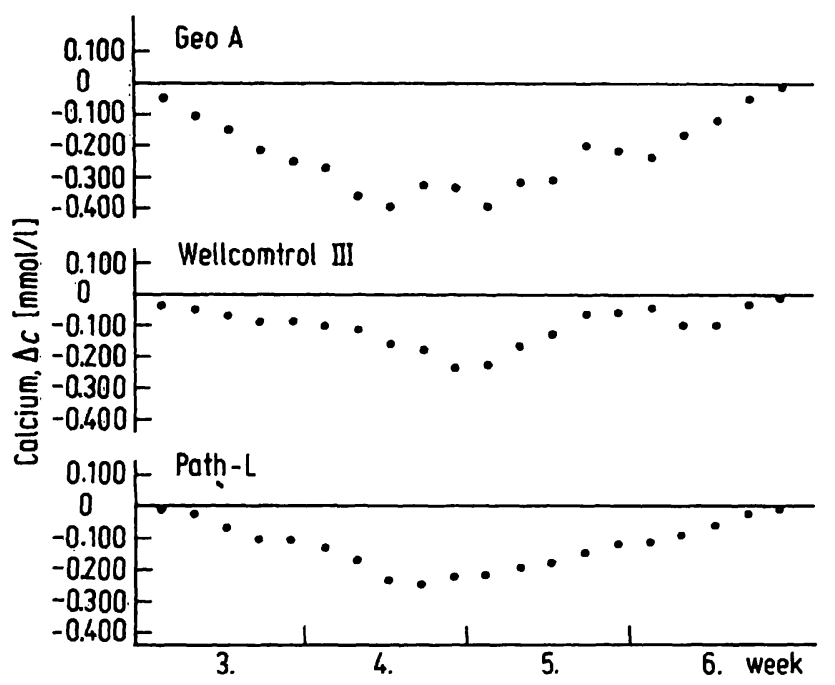

Fig. 2. Cusum-chart of the Ektachem calcium determination for three control sera over a period of four weeks with weekly calibration.

Table 1 contains a summary of all the values from the six-week precision experiment for all control samples and for the four parameters tested: calcium, glucose, urea and uric acid.

Mean values, standard deviations and coefficients of variation are calculated using all the measured values. The precision parameters were evaluated using the following three criteria which are also contained in table 1:

a) comparison with the results of proficiency tests

b) comparison with the claim of the College of American Pathologists (CAP), demanding an analytical dispersion of less than $1 / 16$ th of the normal range.

Upon examination of the precision of the Ektachem and the comparative methods, it is seen that the results clearly favour the Ektachem method, with the exception of calcium. Atomic absorption spectrophotometry is somewhat more precise than the Ektachem method. The precision of all four Ektachem methods is markedly better than the values obtained from proficiency testing. Using the very stringent CAP claim as a basis table 1 shows that this criterion is fulfilled in all control samples for glucose, urea and uric acid determinations. In the calcium determination the precision roughly corresponds with the CAP requirement of $1.7 \%$. Only two control 
Tab. 1. Precision of the calcium, glucose, urea and uric acid determination with the Ektachem method over a period of six weeks, compared with the results of the laboratory method and an interlaboratory survey.

\begin{tabular}{|c|c|c|c|c|c|c|c|c|c|c|c|c|}
\hline & \multicolumn{3}{|l|}{ Calcium } & \multicolumn{3}{|l|}{ Glucose } & \multicolumn{3}{|l|}{ Urea } & \multicolumn{3}{|l|}{ Uric acid } \\
\hline & $\begin{array}{l}\bar{x} \\
(\mathrm{mmol} / \mathrm{l})\end{array}$ & $\begin{array}{l}\text { SD } \\
(\mathrm{mmol} / \mathrm{l})\end{array}$ & $\begin{array}{l}\text { CV } \\
(\%)\end{array}$ & $\begin{array}{l}\overline{\mathbf{x}} \\
(\mathrm{mmol} / \mathrm{l})\end{array}$ & $\begin{array}{l}\text { SD } \\
(\mathrm{mmol} / \mathrm{l})\end{array}$ & $\begin{array}{l}\text { CV } \\
(\%)\end{array}$ & $\begin{array}{l}\overline{\mathbf{x}} \\
(\mathrm{mmol} / \mathrm{l})\end{array}$ & $\begin{array}{l}\text { SD } \\
(\mathrm{mmol} / \mathrm{l})\end{array}$ & $\begin{array}{l}\text { CV } \\
(\%)\end{array}$ & $\begin{array}{l}\overline{\mathrm{x}} \\
(\mu \mathrm{mol} /(1)\end{array}$ & $\begin{array}{l}\text { SD } \\
(\mu \mathrm{mol} / \mathrm{i})\end{array}$ & $\begin{array}{l}\text { CV } \\
(\%)\end{array}$ \\
\hline $\begin{array}{l}\text { Patho- } \\
\text { norm-L }\end{array}$ & 1.37 & 0.0265 & 1.94 & 2.14 & 0.07 & 3.3 & 2.66 & 0.13 & 4.89 & 201 & 3.5 & 1.8 \\
\hline $\begin{array}{l}\text { Hyland } \\
\text { Q-Pak } \\
\text { (Precinorm U } \\
\text { for uric acid) }\end{array}$ & 2.01 & 0.0343 & 1.70 & 4.98 & 0.07 & 1.4 & 5.17 & 0.21 & 4.10 & 282 & 4.3 & 1.5 \\
\hline Monitrol II & 1.96 & 0.0376 & 1.92 & 12.91 & 0.18 & 1.4 & 11.75 & 0.35 & 2.93 & & & \\
\hline $\begin{array}{l}\text { Well- } \\
\text { comtrol II }\end{array}$ & 2.98 & 0.046 & 1.55 & 11.71 & 0.13 & 1.2 & 28.68 & 0.75 & 2.62 & & & \\
\hline $\begin{array}{l}\text { Well- } \\
\text { comtrol III }\end{array}$ & 2.04 & 0.0336 & 1.65 & 3.08 & 0.08 & 2.6 & 14.46 & 0.41 & 2.84 & 36.5 & 5.2 & 1.4 \\
\hline Geo-A & 3.69 & 0.0509 & 1.38 & 27.13 & 0.32 & 1.2 & 31.87 & 0.64 & 2.01 & 843 & 10.8 & 1.3. \\
\hline $\begin{array}{l}\text { Laboratory } \\
\text { method }\end{array}$ & 2.40 & 0.03 & 1.25 & 4.42 & 0.26 & 5.94 & 5.60 & 0.33 & 5.9 & 247 & 7.16 & 2.9 \\
\hline $\begin{array}{l}\text { Inter- } \\
\text { laboratory } \\
\text { survey }\end{array}$ & $\begin{array}{c}2.96 \\
(n=38) \\
\vdots \vdots\end{array}$ & 0.156 & 5.3 & $\begin{array}{c}4.82 \\
(n=410)\end{array}$ & 0.39 & 8.1 & $\begin{array}{c}5.78 \\
(n \equiv 299)\end{array}$ & 0.76 & 13.1 & $\begin{array}{l}264 \\
(n=82)\end{array}$ & 32.4 & 12.1 \\
\hline CAP claim & & & 1.7 & & & 3.8 & & & 6.3 & & & 5.0 \\
\hline
\end{tabular}

samples with a very low calcium concentration (Pathonorm-L and Monitrol II) resulted in a slightly higher coefficient of variation ( $1.94 \%$ and $1.92 \%$, respectively).

All the values from three control samples for each test parameter were subjected to two separate analysis of variance (ANOVA) techniques: one for the data set generated with daily calibration and one for that with weekly calibration. The results are shown in table 2 , whereby the total variability $S_{\text {total }}$ is split into the individual components of variance. For the individual components of variance in the calcium determination it is not possible to recognize any definite trend, i.e. they are all of a similar order of magnitude. For glucose, urea and uric acid however the variance component introduced by calibration has the major share in the total variance. It is worth noting that the components of day-to-day variability are not larger than those of run-to-run or within-run variability. This is another indication of the high long-term stability of both analyzer and slides. There is also no systematic difference visible when comparing the total variability obtained using daily and weekly calibration. All the results of the precision study which we gained.for the glucose and urea determinations using the Kodak Ektachem Four Chemistry Analyzer confirm the experiences of authors (6-9) who evaluated the Kodak Ektachem Glu/Bun Analyzer.

Tab. 2. Results of the analysis of variance (ANOVA).

Components of variance: $\dot{S}_{\mathrm{Cal}}=$ variability caused by the calibration procedure

$$
\begin{aligned}
S_{\mathrm{AM} / \mathrm{PM}} & =\text { within-day variability } \\
\mathrm{S}_{\text {Total }} & =\text { total variability }
\end{aligned}
$$

$S_{\text {Day }}=$ day-to-day variability

$\mathrm{S}_{\mathrm{Rep}}=$ within-run variability

\begin{tabular}{|c|c|c|c|c|c|c|c|c|c|c|c|}
\hline & & \multicolumn{3}{|c|}{ Daily calibration ( 2 weeks) } & \multicolumn{6}{|c|}{ Weekly calibration ( 4 weeks) } & \multirow[t]{2}{*}{$\overline{\mathbf{x}}$} \\
\hline & & $\mathrm{S}_{\mathrm{Cal}}$ & $\mathrm{S}_{\mathrm{AM} / \mathrm{PM}}$ & $S_{\text {Rep }}$ & S Total $_{\text {Th }}$ & $\mathrm{S}_{\mathrm{Cal}}$ & $S_{\text {Day }}$ & $\mathrm{S}_{\mathrm{AM} / \mathrm{PM}}$ & $\mathrm{S}_{\text {Rep }}$ & S Total & \\
\hline $\begin{array}{l}\text { Calcium } \\
(\mathrm{mmol} / \mathrm{l})\end{array}$ & $\begin{array}{l}\text { Pathonorm-L } \\
\text { Wellcomtrol-II } \\
\text { Geo-A }\end{array}$ & $\begin{array}{l}0 \\
0.003 \\
0.010\end{array}$ & $\begin{array}{l}0.027 \\
0.021 \\
0.036\end{array}$ & $\begin{array}{l}0.013 \\
0.014 \\
0.035\end{array}$ & $\begin{array}{l}0.030 \\
0.025 \\
0.051\end{array}$ & $\begin{array}{l}0.028 \\
0.038 \\
0.035\end{array}$ & $\begin{array}{l}0.005 \\
0.030 \\
0.044\end{array}$ & $\begin{array}{l}0,020 \\
0.014 \\
0.026\end{array}$ & $\begin{array}{l}0.014 \\
0.023 \\
0.029\end{array}$ & $\begin{array}{l}0.0375 \\
0.055 \\
0.068\end{array}$ & $\begin{array}{l}1.366 \\
2.976 \\
3.694\end{array}$ \\
\hline $\begin{array}{l}\text { Glucose } \\
(\mathrm{mmol} / \mathrm{l})\end{array}$ & $\begin{array}{l}\text { Pathonorm-L } \\
\text { Wellcomtrol-II } \\
\text { Geo-A }\end{array}$ & $\begin{array}{l}0.106 \\
0.088 \\
0.143\end{array}$ & $\begin{array}{l}0.024 \\
0.060 \\
0.036\end{array}$ & $\begin{array}{l}0.034 \\
0.054 \\
0.179\end{array}$ & $\begin{array}{l}0.11 \\
0.12 \\
0.23\end{array}$ & $\begin{array}{l}0.035 \\
0.083 \\
0.30\end{array}$ & $\begin{array}{l}0.021 \\
0.061 \\
0.17\end{array}$ & $\begin{array}{l}0.016 \\
0.088 \\
0.20\end{array}$ & $\begin{array}{l}0.024 \\
0.084 \\
0.08\end{array}$ & $\begin{array}{l}0.05 \\
0.16 \\
0.41\end{array}$ & $\begin{array}{l}2.139 \\
\cdot 11.71 \\
27.12\end{array}$ \\
\hline $\begin{array}{l}\text { Urea } \\
\text { (mmol/1) }\end{array}$ & $\begin{array}{l}\text { Pathonorm-L } \\
\text { Wellcomtrol-II } \\
\text { Geo-A }\end{array}$ & $\begin{array}{l}0.23 \\
0.65 \\
0.66\end{array}$ & $\begin{array}{l}0.08 \\
0 \\
0.18\end{array}$ & $\begin{array}{l}0.06 \\
0.28 \\
0.56\end{array}$ & $\begin{array}{l}0.25 \\
0.71 \\
0.88\end{array}$ & $\begin{array}{l}0.10 \\
0.61 \\
0.45\end{array}$ & $\begin{array}{l}0 \\
0.36 \\
0.35\end{array}$ & $\begin{array}{l}0.17 \\
0.36 \\
0.27\end{array}$ & $\begin{array}{l}0: 0.5 \\
0.24 \\
0: 36\end{array}$ & $\begin{array}{l}0.20 \\
0.82 \\
0.73\end{array}$ & $\begin{array}{r}2.742 \\
28.493 \\
31.638\end{array}$ \\
\hline $\begin{array}{l}\text { Uric acid } \\
\text { ( } \mu \mathrm{mol} / \mathrm{l})\end{array}$ & $\begin{array}{l}\text { Pathonorm-L } \\
\text { Wellcomtrol-III } \\
\text { Geo-A }\end{array}$ & $\begin{array}{l}3.52 \\
5.59 \\
8.05\end{array}$ & $\begin{array}{l}1.57 \\
1.88 \\
4.48\end{array}$ & $\begin{array}{l}3.62 \\
2.81 \\
6.08\end{array}$ & $\begin{array}{r}5.28 \\
6.53 \\
11.04\end{array}$ & $\begin{array}{r}2.34 \\
4.47 \\
10.67\end{array}$ & $\begin{array}{l}0.95 \\
1.56 \\
4.66\end{array}$ & $\begin{array}{l}0.96 \\
1.06 \\
1.73\end{array}$ & $\begin{array}{l}2.19 \\
2.40 \\
5.24\end{array}$ & $\begin{array}{r}3.47 \\
5.42 \\
12.89 \\
\end{array}$ & $\begin{array}{l}200.96 \\
364.47 \\
843.04\end{array}$ \\
\hline
\end{tabular}

$\bar{x}=$ mean over the total period of 6 weeks 


\section{Estimation of accuracy}

\section{Method comparison using patients' sera}

The accuracy of the four Ektachem methods was studied by comparative measurement of the same patients' sera using our laboratory method. No sera were excluded. Haemolytic and lipaemic sera as well as sera from dialysis patients were included in the study. The sera were analysed with both methods on the same day. In cases where the differences were larger than $10 \%$ the sera were analysed again using both methods. No outliers were eliminated. The results of the method comparison experiment are summarized in figures 3-6 and in table 3.

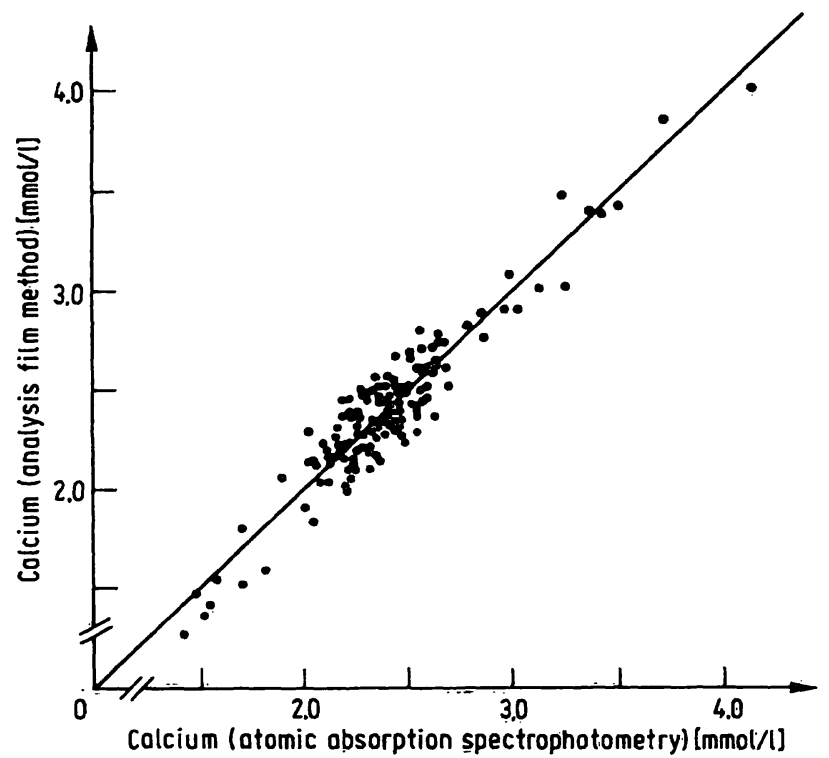

Fig. 3. Linear regression plot comparing Ektachem results with those by the atomic absorption spectrophotometry ( $n=143$ patients.' sera).

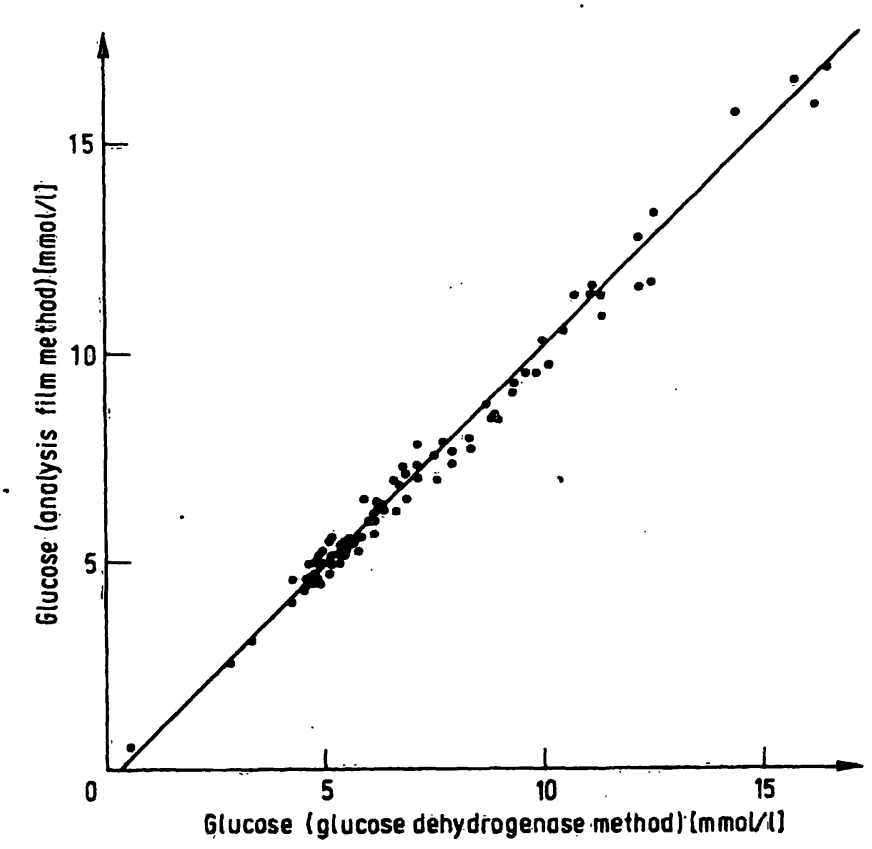

Fig. 4. Linear regression plot comparing Ektachem results with those by the glucose dehydrogenase method ( $n=98$ patients' sera).

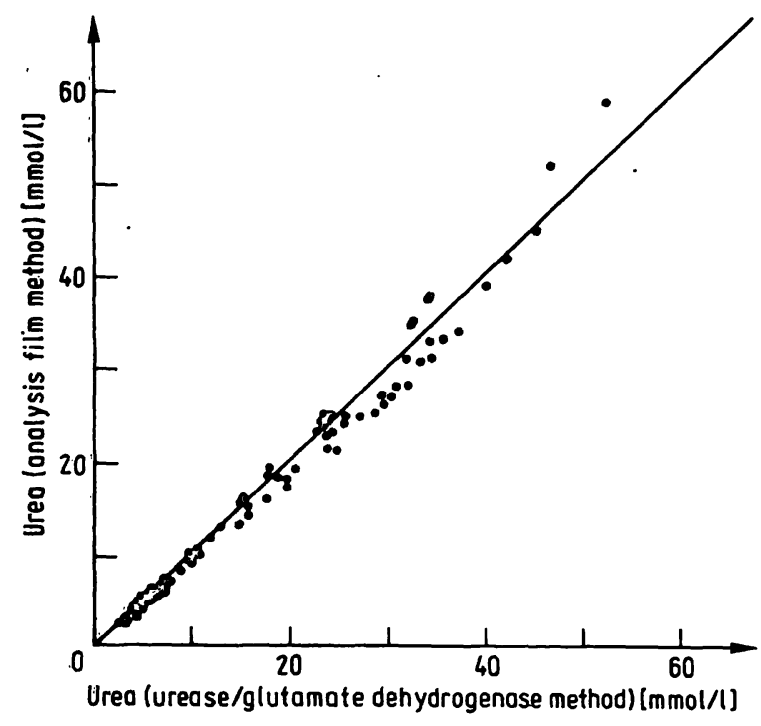

Fig. 5. Linear regression plot comparing Ektachem results with those by the urease/glutamate dehydrogenase method ( $\mathrm{n}=98$ patients' sera).

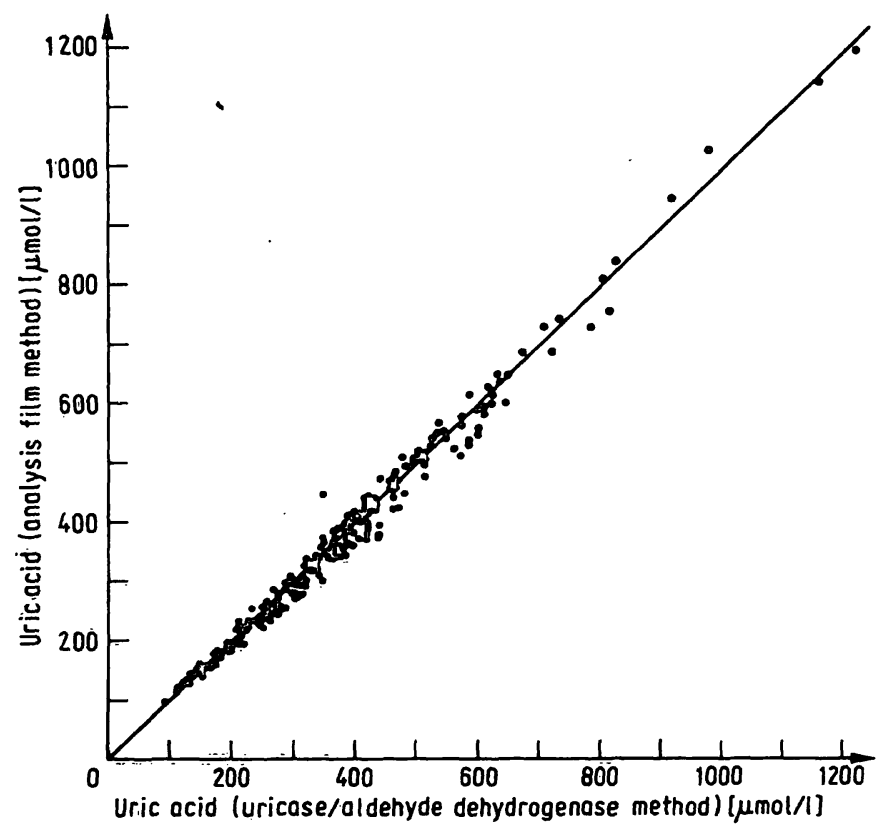

Fig. 6. Linear regression plot comparing Ektachem results with those by the uricase/aldehyde dehydrogenase method ( $\mathrm{n}=232$ patients' sera).

The correlation coefficients for the glucose, urea and uric acid determinations are very close to unity $(>0.99)$ and the somewhat lower correlation coefficient of $r=0.946$ for calcium is due to the low concentration range of calcium in the sera investigated. The differences in the mean values of the Ektachem methods and the comparative methods were tested for statistical significance using the t-test for paired data (see table 3). For the glucose determination it was not possible to reject the zero hypothesis; for calcium the difference was significant at the $5 \%$ level, and for uric acid and urea significant at the $1 \%$ and $0.1 \%$ level, respectively. A study of the averaged differences however (calcium: $\overline{\mathrm{d}}=0.022 \mathrm{mmol} / \mathrm{l}$; urea: $\overline{\mathrm{d}}=0.678 \mathrm{mmol} / \mathrm{l}$; uric acid: $\overline{\mathrm{d}}=5.06 \mu \mathrm{mol} / \mathrm{l}$ ) shows no clinical relevance. 
Tab. 3. Method comparison with patients' sera.

$\left.\begin{array}{ll}\text { n.s. = not significant } & 1\end{array}\right)$ significant different from $\beta_{y x}=1(p<0.01)$

$n=$ number of sera $\left.\quad{ }^{2}\right)$ significant different from $\alpha_{y x}=0(p<0.01)$

\begin{tabular}{|c|c|c|c|c|c|c|c|}
\hline \multirow[b]{2}{*}{ Mean concentration $\bar{x}$} & \multicolumn{2}{|c|}{$\begin{array}{l}n=143 \\
\text { Calcium } \\
x=\text { Laboratory method } \\
y=\text { Ektachem method }\end{array}$} & \multicolumn{2}{|c|}{$\begin{array}{l}\mathrm{n}=98 \\
\text { Glucose } \\
\mathrm{x}=\text { Laboratory method } \\
\mathrm{y}=\text { Ektachem method }\end{array}$} & $\begin{array}{l}n=98 \\
\text { Urea } \\
x=\text { Laboratory method } \\
y=\text { Ektachem method }\end{array}$ & \multicolumn{2}{|c|}{$\begin{array}{l}\mathrm{n}=232 \\
\text { Urie acid } \\
\mathrm{x}=\text { Laboratory method } \\
\mathrm{y}=\text { Ektachem method }\end{array}$} \\
\hline & 2.4125 & $\mathrm{mmol} / 1$ & 7.649 & mmol/1 & $16.251 \mathrm{mmol} / 1$ & 369.24 & $\mu \mathrm{mol} / 1$ \\
\hline Standard deviation $S_{x}$ & 0.383 & $\mathrm{mmol} / \mathrm{l}$ & 4.101 & $\mathrm{mmol} / 1$ & $12.672 \mathrm{mmol} / 1$ & 183.46 & $\mu \mathrm{mol} / 1$ \\
\hline Mean concentration $\bar{y}$ & 2.390 & $\mathrm{mmol} / \mathrm{l}$ & 7.636 & $\mathrm{mmol} / \mathrm{l}$ & $15.582 \mathrm{mmol} / 1$ & 374.30 & $\mu \mathrm{mol} / 1$ \\
\hline Standard deviation $\mathrm{S}_{\mathrm{y}}$ & 0.397 & $\mathrm{mmol} / \mathrm{l}$ & 4.292 & $\mathrm{mmol} / 1$ & $12.481 \mathrm{mmol} / 1$ & 190.29 & $\mu \mathrm{mol} / 1$ \\
\hline Difference $\overline{\mathrm{d}}=\frac{\Sigma\left(\mathrm{x}_{\mathrm{i}}-\mathrm{y}_{\mathrm{i}}\right)}{\mathrm{n}}$ & 0.02238 & $3 \mathrm{mmol} / \mathrm{l}$ & 0.0166 & $3 \mathrm{mmol} / \mathrm{l}$ & $0.6778 \mathrm{mmol} / 1$ & -5.062 & $\mu$ mọol/1 \\
\hline$s_{\bar{d}}$ & 0.01077 & $\mathrm{mmol} / \mathrm{l}$ & 0.0420 & $\mathrm{mmol} / 1$ & $0.1613 \mathrm{mmol} / 1$ & 1.528 & $\mu \mathrm{mol} / \mathrm{l}$ \\
\hline$\hat{\mathrm{t}}=\overline{\mathrm{d}} / \mathrm{S}_{\overline{\mathrm{d}}}$ & 2.08 & $\mathrm{mmol} / \mathrm{l}$ & 0.396 & & 4.20 & -3.31 & \\
\hline Significance & $\mathrm{p}<0.05$ & & n.s. & & $\mathrm{p}<0.001$ & $\mathrm{p}<0.01$ & \\
\hline Slope $b_{y x}$ & 0.9820 & & 1.0429 & & 0.9773 & 1.0299 & \\
\hline$S_{b_{y x}}$ & 0.0283 & & 0.0093 & & 0.0127 & 0.0081 & \\
\hline Intercept $\mathbf{a}_{\mathbf{y x}}$ & 0.0209 & $\mathrm{mmol} / 1$ & -0.3455 & $\left.\mathrm{mmol} / \mathrm{l}^{2}\right)$ & $-0.3090 \mathrm{mmol} / 1$ & -5.976 & $\mu \mathrm{mol} / 1$ \\
\hline $\mathrm{S}_{\mathrm{a}_{\mathbf{y x}}}$ & 0.0690 & $\mathrm{mmol} / 1$ & 0.0812 & $\mathrm{mmol} / 1$ & $0.2607 \mathrm{mmol} / 1$ & 3.35 & $\mu \mathrm{mol} / 1$ \\
\hline$S_{y . x}$ & 0.1290 & $\mathrm{mmol} / \mathrm{l}$ & 0.3783 & $\mathrm{mmol} / \mathrm{l}$ & $1.582 \mathrm{mmol} / \mathrm{l}$ & 22.66 & $\mu \mathrm{mol} / 1$ \\
\hline Correlation coefficient $\mathbf{r}$ & 0.9462 & & 0.9961 & & 0.9920 & 0.9929 & \\
\hline
\end{tabular}

Calculation of the line of regression resulted in the following $($ Ektachem method $=y)$ :

Calcium: $y=0.0209+0.9820 x$

Glucose: $y=-0.3455+1.0429 x$

Urea: $\quad y=0.3090+0.9773 x$

Uric acid: $y=-5.976+1.0299 x$

Slopes $\left(b_{y x}\right)$ and intercepts $\left(a_{y x}\right)$ for the regression lines were tested to establish whether they were significantly different from $\beta_{\mathrm{yx}}=1$ or $\alpha_{\mathrm{yx}}=0$, respectively. This calculation resulted in a statistically significant difference for glucose in the intercept as well as the slope, for uric acid only in the slope (each $p<0.01$ ). This is not due to the magnitude of $b_{y x}$ and $a_{y x}$ but to the low dispersion $S_{b_{y x}}$ and $S_{a y x}$ of these two parameters. For calcium and urea determinations neither the slope nor the intercept of the regression line showed any significant bias from $\beta_{y x}=1$ or $\alpha_{y x}=0$, respectively. Table 3 also contains the values of $s_{y . x}$, the residual variability, which is an estimate of the dispersion along the regression line.

In total, the analysis of patients' sera using the Ektachem methods and the laboratory methods results in good agreement. The slight deviations are practically insignificant.

\section{Method comparison using proficiency samples}

The accuracy of the Ektachem methods was also tested by a method comparison using proficiency samples. The results are summarized in table 4.
All the values for the calcium determination using the Ektachem method lay within the assigned interval and were all approximately $0.2 \mathrm{mmol} / 1$ lower than the values obtained with the comparative method.

Glucose and uric acid determinations using the Ektachem method correlated well with the respective comparative methods. Results were all within the assigned interval.

The Ektachem method for urea determination showed high negative deviation in comparison with the laboratory method (about $2 \mathrm{mmol} / 1$ on average). Results for all proficiency samples were below the assigned interval. The manufacturer is aware that low carbon dioxide concentrations may cause a negative bias and to compensate for this it is therefore recommended that proficiency samples be reconstituted with bicarbonate solution (15-25 mmol/l). In our experiments proficiency samples were also reconstituted with $20 \mathrm{mmol} / \mathrm{l}$ of bicarbonate solution and although this led to a significant increase in urea concentrations, only proficiency sample B in the second proficiency test was able to achieve the assigned interval.

\section{Method comparison using accuracy control samples}

In a further range of experiments a set of 12 accuracy control samples (Wellcome Reagents Ltd.) were analysed with the routine laboratory method and the Ektachem method. The calcium values obtained with the Ektachem method showed an average bias of - 1.9.\%.(range $(-5.4)$ $(+3.6) \%)$ and with the comparison method, atomic 


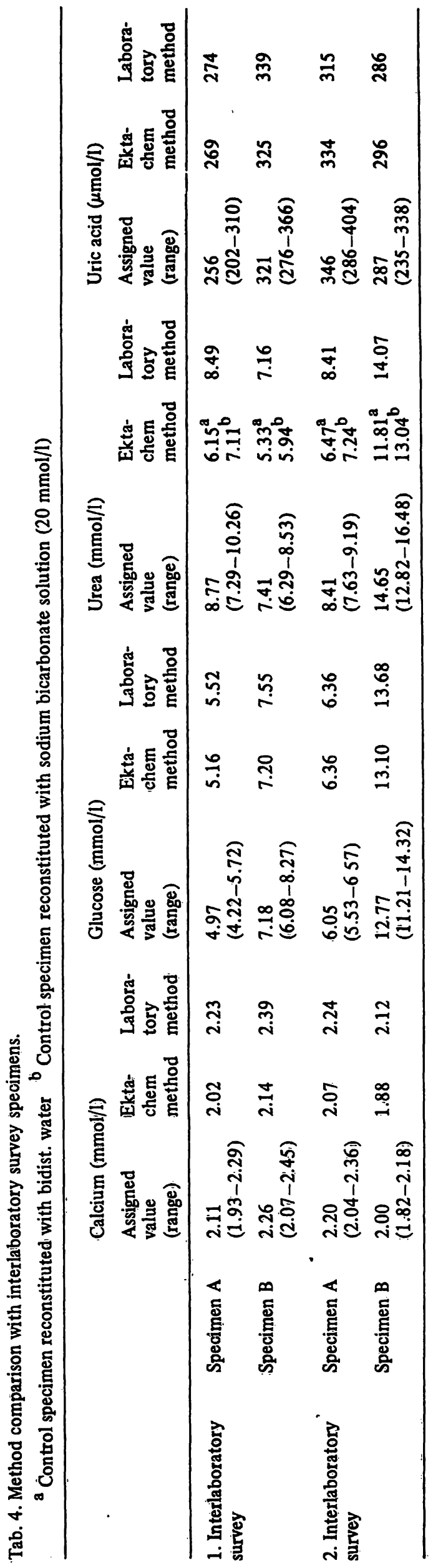

absorption spectrophotometry $+1.0 \%$ (range $(-6.5)-$ $(+7.2) \%)$. The negative bias for these accuracy control samples on the Ektachem analyzer is lower than that which resulted from proficiency sample tests.

The Ektachem method for glucose showed an average bias of $-2.4 \%$ (range $(-4.4)-(+0.7) \%$ ); the comparison method showed $+0.7 \%$ (range $(-6.3)-(+5.4) \%)$.

The results obtained for urea showed a trend similar to, but smaller than, the results from the proficiency samples. The Ektachem method showed an average bias of $-6.9 \%$ (range $(-15)-(0.7) \%$ ), the comparative method of $+4 \%$ (range $(-7.7 \%)-(+25.5 \%)$.

The average bias of the Ektachem uric acid determination was $-3.2 \%$ (range $(-5.7)-(-0.5) \%$ ) which was however only half the size of the average bias of the comparison method which was $-7.1 \%$ (range $(-12.4)$ $(+1.2) \%)$.

\section{Line arity}

For the four determinations, the following concentrations are the maximum at which a linear dependence on concentration was found:

Calcium: up to $4.2 \mathrm{mmol} / 1$

Glucose: up to $33 \mathrm{mmol} / \mathrm{l}$

Urea: up to $60 \mathrm{mmol} / \mathrm{l}$

Uric acid: up to $1370 \mu \mathrm{mol} / 1$

The linear range for all four parameters is so large that, in practice, dilution of serum is only seldom required.

\section{Conclusions}

From the results of the comparison carried out between the new multilayer film technology and the conventional "wet" chemistry methods, it can be concluded that they are equally accurate. As regards precision, linear range and practicability the Ektachem method is proved to be superior to wet chemistry methods. Some problems were encountered with the determination of urea in control samples however, probably due to matrix effects. One advantage of the new technology is that after serum is metered onto a slide, no further pipetting steps are necessary. The system is fairly insensitive to slight differences in volume applications, since the density of the coloured compound formed is constant over the whole reaction zone and only a small area in the centre is used for the final measurement of reflection density. The analyzer is simple to operate and only a minimal amount of space is required to store slide supplies. When further methods - enzymes in particular - are developed using the multilayer film technique, this technology will provide a real alternative to conventional wet chemistry procedures. 


\section{References}

1. Curme, H. G., Columbus, R. L., Dappen, G. M., Eder, T. W., Fiellows, W. D., Figueras, J., Glover, C. P., Goffe, C. A., Hill, D. E., Lawton, W. H., Muka, E. J., Pinney, J. E., Rand, R. N., Sanford, K. J. \& Wu, T. W. (1978) Clin. Chem. 24, 13351342.

2. Spayd, R. W., Bruschi, N., Burdick, B. A., Dappen, G. M., Eikenberry, J. N., Esders, T. W., Figueras, J., Goodhue, C. T., LaRossa, D. D., Nelson, R. W., Rand, R. N. \& Wu, T. W. (1978) Clin. Chem. 24, 1343-1350.

3. Haeckel, R. (1979) GIT Labor-Medizin 2, 201-205.

4. Tietz, N. W. (1976) in Fundamentals of Clinical Chemistry, 2nd ed., Philadelphia, W. B. Saunders Co., p. 908.

5. Trinder, P. (1969) Ann. Clin. Biochem. 6, 24-27.

6. Haeckel, R. \& Sonntag, O. (1979) GIT Labor-Medizin 2, 317-327.

7. Cate, J. C., Hedrick, R., Taylor, M. \& McGlothlin, C. D. (1980) Clin. Chem. 26, 266-270. . ।

8. Warren, K., Kubasik, N. P., Brody, B. B., Sine, H. E. \& D'Souza, J. P. (1980) Clin. Chem. 26, 133-137

9. Bandi, Z. L., Fuller, J. B., Bee, D. E. \& James, G. P. (1981) Clin. Chem. 27, 27-34.

Dr. Ernst Knoll

Department of Clinical Chemistry

Robert-Bosch-Krankenhaus

Aueribachstriaße 110

D-7000 Stuttgart 50 